\section{Organizational identification in school psychological counselors: The role of psychological empowerment and self-efficacy beliefs}

Okul psikolojik danışmanlarında örgütsel özdeşleşme: Psikolojik güçlendirme ve öz-yeterlik inançlarının rolü

\author{
Serdal Özgözgü ${ }^{1}$ \\ Mahmut Bektaş $^{2}$
}

\begin{abstract}
If the psychological counselors who work at schools feel themselves strong and sufficient, this will strengthen their bond with school environment and contribute to their identification with the school. In this research, it is aimed to determine the general self-efficacy, psychological empowerment and the perception of the organizational identification of the psychological counselors who work in schools and to see if the general self-efficacy and the psychological empowerment will predict the organizational identification. "Psychological Empowerment Scale", "General Self-Efficacy Scale" and "Organizational Identification Scale" are used to collect data. The data is collected by the 374 psychological counselors who work in the schools in Izmir. As a result of the research, the school psychological counselors' perception of general self-efficacy, psychological empowerment and organizational identification increased above average. In addition, moderate significant relation is found between variables. Nonetheless, the perception of general selfefficacy and psychological empowerment predict the organizational identification on a significant level.
\end{abstract}

\section{Özet}

Okullarda görev yapan okul psikolojik danışmanlarının kendilerini psikolojik olarak güçlü ve yeterli hissetmeleri, okulları ile olan bağlarını kuvvetlendirerek özdeșleșmelerine katkıda bulunmaktadır. Araştırmada okullarda görev yapan okul psikolojik danışmanlarının genel öz-yeterlik, psikolojik güçlendirme ve örgütsel özdeşleme algılarını belirlemek ve genel öz-yeterlik ile psikolojik güçlendirme algılarının örgütsel özdeşlemeyi yordayıp yordamadığına bakılması amaçlanmıştur. Araştırmada veri toplamak için "Psikolojik Güçlendirme Ölçeği", "Genel Öz Yeterlik Ölçeği" ve "Örgütsel Özdeşleşme Ölçeği" kullanılmıştır. İzmir'deki okullarda çalışan 374 psikolojik danışmandan veri toplanmıştır. Araştırma sonucunda okul psikolojik danışmanlarının genel öz-yeterlik, psikolojik güçlendirme ve örgütsel özdeşleşme alg1lar1 orta düzeyin üzerinde çıkmıştur. Araştırmada ayrıca değişkenler arasında orta düzeyde anlamlı ilişki bulunmuştur. Ayrıca genel öz-yeterlik ve psikolojik güçlendirme alg1s1 örgütsel özdeșleșmeyi anlamlı derecede yordamaktadir.

1Dr., MEB, serdales@gmail.com. 
Özgözgü, S., \& Bektaș, M. (2018). Okul psikolojik danışmanlarında örgütsel özdeşleșme: Psikolojik güçlendirme ve özyeterlik inançlarının rolü. Journal of Human Sciences, 15(4), 1993-2011. doi:10.14687/jhs.v15i4.5372

Keywords: Organizational identification; Anahtar Kelimeler: Örgütsel özdeşleşme; Psychological empowerment; Self-efficacy; Psikolojik güçlendirme; Öz-yeterlik; Psikolojik Psychological Counselor; School. Danışman; Okul.

(Extended English summary is at the end of this document)

\section{Giriş}

Ülkemizde çağdaş eğitim anlayışı doğrultusunda okullarda yürütülen çalışmaların öğretim, yönetim ve öğrenci kişilik hizmetleri $(\mathrm{O} K H)$ olmak üzere üç temel kategori altında sınıflandırılabileceğini belirten Yeşilyaprak'a (2006) göre, ÖKH kapsamında değerlendirilebilecek rehberlik faaliyetleri içerisinde, profesyonel bir uzman tarafindan yürütülmesi gereken çeşitli iş tanımları ve faaliyetler bulunmaktadır. Bu amaçla, okullardaki rehberlik hizmetlerinin etkili ve amacına uygun bir şekilde sürdürülebilmesi için Okul Psikolojik Danışma ve Rehberlik (PDR) Servislerinde çalışan uzmanlar etkin sorumluluklar üstlenmektedirler.

Türkiye'de 1950'li ylllardan günümüze rehberlik hizmetleri giderek daha fazla görünür hale gelmekle birlikte (Kuzgun, 1991) okulun paydaşlarının bu hizmet için oluşturdukları algı hiç de beklenildiği gibi olmamıştır. Konu ile ilgili yapılan bir çalışmada Karataş ve Şahin Baltacı (2013), paydaşların PDR hizmetlerine ilişkin görüşlerini incelemişlerdir. Buna göre PDR hizmetleri, okul müdürleri, öğretmenler ve öğrenciler tarafindan daha çok "yol gösterme, dert ortaklığ1, problem çözme, yardım birimi” diye tanımlanmaktadır. Aynı araştırmada okul psikolojik danışmanları tarafından ise "psikolojik yardım, seçenek sunma, yöneltme ve yol gösterme" olarak değerlendirilmiştir. Ünal ve Ünal'ın (2010) öğretmen ve öğrencilerle gerçekleştirdikleri araştırmada okul psikolojik danışmanı "bilgi verici, yararlı, çalışkan, hayatı güzelleştiren, sakınılması gereken, güven duyulan, sabırlı ve demokrat" biri olarak görülmüştür. PDR hizmetlerine ilişkin okul yöneticilerinin görüşlerini inceleyen başka bir araştırmada ise (Özabacı, Sakarya \& Doğan, 2008) okuldaki yöneticiler, "psikolojik danışmanların öğrencileri bire bir tanımalarının önemli olduğunu; öğrencilerin kendilerini tanımalarını kolaylaştıracak ilgi, yetenek ve ihtiyaç tespitlerinin yapılabilmesi için her okulun PDR servisinde en az bir uzmanın bulundurulması gerektiğini”" ifade etmişlerdir.

PDR hizmetleri, çağdaş eğitim ve öğretim süreçlerinin en önemli bileşenlerindendir. Bu hizmetlerin yerine getirilmesinde aktif görev alan okul psikolojik danışmanlarının (Rehberlik Öğretmenlerinin) mesleki bakımdan kendilerini yetkin düzeyde görmeleri; PDR hizmetlerinin etkililiği, verimliliği ve aynı zamanda amacına uygun bir şekilde yürütülebilmesi açısından önemlidir. Psikolojik danışmanların yaşanabilecek önemli kriz durumlarında ve engellemeler karşısında kendini psikolojik olarak güçlü hissedebilmesi ve öz-yeterlik inançlarının yüksek olması büyük önem taşımaktadır.

Okul PDR servislerinde görevli psikolojik danışmanlar, hem içinde bulundukları örgütün amaçlarının gerçekleştirilmesine katkı sunarlar hem de içinde bulundukları örgütün özelliklerinden faydalanırlar. Bireyin amaçlan ile örgütün amaçlanının birbirini olumlu yönde etkilediği durumlarda birey örgütüne karşı daha fazla bağlllık geliştirirken çalışanların bu bağlllıkları örgütün amaçları ile kendi amaç ve çıkarlarını özdeşleştirmelerini sağlayabilmektedir. Bu durum bireyin örgütüyle özdeşleşmesi ve kimlik birliği kurması anlamına gelmektedir (Eren, 2015: 555). Bu özdeşleşmenin de etkisiyle, bireyler örgütlerine ilişkin olumlu öz-değerlendirmeler yaparlar ve üyesi oldukları grubu diğer gruplardan daha üstün görürler (Demirtaş, 2003: 124). Bu sonuç, bireylerin içinde bulundukları grupla olan özdeşleşme bağlarını güçlendirir.

Alan yazında bireyin özdeşleşmesi "Sosyal Kimlik Kuramı” ile açıklanmaya çalışılmıştır. Buna göre birey, benlik kavramı, yetenekler ve ilgiler gibi kendine özgü özellikleri kapsayan kişisel bir kimlik ile belirli grup sınıflandırmalarını kapsayan sosyal bir kimlikten meydana gelmektedir (Tajfel ve Turner, 1985'ten aktaran Mael \& Ashforth, 1992: 104). "Sosyal Kimlik Kuramı"na göre 
Özgözgü, S., \& Bektaș, M. (2018). Okul psikolojik danışmanlarında örgütsel özdeşleșme: Psikolojik güçlendirme ve özyeterlik inançlarının rolü. Journal of Human Sciences, 15(4), 1993-2011. doi:10.14687/jhs.v15i4.5372

Özdeşleşme, kişinin sosyal bir nesne ile ilişkisinin kişisel sunumudur (Brown, 1969: 347). Ashforth ve Mael'e (1989: 34) göre özdeşleşme; "başarı ve başarısızlık durumlarını da kapsayan, bir gruba ait olma ya da birlik olma algısı”dır. Örgütsel özdeşleşme kişiler ile çalıştıkları örgüt arasındaki ilişkiyi açıklamanın bir yoludur (Bartels, 2006). Örgütsel özdeşleşme, bireyin kendisini üyesi olduğu örgütle tanımlayarak örgütle bir olma ve örgüte aidiyet algısına sahip olmasıdır (Mael \& Ashforth, 1992: 104). Birey, içinde yer aldığ1 grubu kendi kimliği ile benzeştirir. Dolayısıyla, çalışanlar örgütün amaçlarını gerçekleştirmek için daha istekli olurlar. Van Dick (2001) grup özdeşleşmesi ve performans ilişkisi konusunda, örgütsel özdeşleşmenin artmasının, bireyin performansının da artmasına yol açacağını söylemiştir. Barker ve Tompkins'e (1994'den aktaran Ertürk, 2010: 409) göre örgütlerde, belirsizliklerin ve kaygı durumlarının azaltılabilmesi için çalışanların örgütleriyle daha fazla özdeşim kurmaları önem taşımaktadır. Bundan dolayı da örgüt yöneticileri çalışanların performansları üzerinde olumlu etki yapacağına inandıklarından, üyelerin örgütleri ile özdeşleşmesini güçlendirmek isterler (Fiol, 2001: 694). Örgütsel analiz çalışmaları, yaşanan hızlı ve karmaşık sosyal değişimlerin, örgütsel özdeşleşmenin önemini büyük ölçüde arttırdığını göstermektedir. Öte yandan çalışanların örgütleri ile kurdukları özdeşimler, onların çalışma davranışlarının anlaşılmasının önemli bir faktörüdür (Lee, 1971: 213).

Örgütsel özdeşleşmenin sağlanması, bireyin örgüt ile bağ kurmasını gerektirir. Bu bağın kurulması, bireyin kendini örgüt içinde güçlü ve yeterli hissetmesine bağlıdır. Psikolojik güçlendirme ve örgütsel özdeşleşme karşllklı olarak birbirlerini etkileyen süreçlerdir. Kendini güçlendirilmiş hisseden çalışan işi ile ilgili daha fazla tatmin olacak ve böylece örgütüyle daha fazla özdeşleşecektir (Prati \& Zani, 2013: 852-853). Araştırmaların gösterdiği üzere bireyin örgütü ile özdeşleşmesine, genel olarak kendini yeterli ve örgüt içinde psikolojik olarak güçlendirilmiş hissetmesi önemli katkı yapacaktur.

Thomas ve Velthouse (1990: 666-667) güçlendirmeyi çalışanların motivasyonunu belirleyen ve görev değerlendirmesi olarak adlandırılan bilişsel değişkenlerdeki değişimler yönüyle ele almıştır. Spreitzer'e (1995) göre psikolojik güçlendirme, bilişsel faktörlerden oluşan motivasyonel bir yapıdır. Conger ve Kanungo (1988: 474) ise güçlendirmeyi bir yetki devri olmaktan çok motivasyonel olarak etkin hale getirmek olarak ele almışlardır. Laschinger, Finegan, Shamian, ve Wilk'e (2004: 529) göre psikolojik güçlendirme; örgütteki yapısal güçlendirme koşullarını bir örgütteki çalışanların, psikolojik olarak yorumlama ve anlamlandırma biçimlerini yansıtmaktadır.

Güçlendirme uygulamaları iş çıktılarını (kalite, verimlilik, memnuniyet) ve çalışanların bilişsel durumlanını (öz-yeterlik, motivasyon, iş doyumu) etkilemektedir (Bolat, 2003; Conger \& Kanungo, 1988; Fernandez \& Moldogaziev, 2011; Menon, 2001). Ayrıca güçlendirme girişimleri, çalışanlara işlerini yetkin bir şekilde yapabilme hissini sağlar (Thomas \& Velthouse, 1990: 666). Bu anlamda, psikolojik olarak güçlenmiş PDR uzmanları yaptıkları işin anlamı, işe dair yetkinlikleri, işteki özerklik düzeyleri ve paydaşlanı etkileme kapasiteleri gibi bilişsel boyutlarda da güçlenme firsatı yakalarlar. Psikolojik olarak güçlenmiş uzmanların kendi kapasite ve yeteneklerini geliştirme firsatı bulmaları, aynı zamanda psikolojik yardım hizmeti sundukları öğrenci, öğretmen ve velilerin kapasitelerini arttıracak faaliyetlere ağılık verme sorumluluklarında da bir artış beklenebilir. Ek olarak, pozitif psikoloji hareketinin de etkisiyle psikolojik olarak güçlenmiş PDR uzmanları tarafindan yurt içinde ve yurt dışında pek çok önleyici ve gelişimsel çalışmaların yürütüldüğ̈ görülmektedir (Eryılmaz, 2013).

Spreitzer'in (1995) psikolojik güçlendirme bileşenlerinden olan yetkinlik, Bandura'nın (1977, 1986) üzerinde çalıştı̆̆ öz-yeterlik kavramı ile ilgilidir. Bu anlamda psikolojik güçlendirmenin bileşenlerinden olan özerklik ihtiyacı veya öz-yeterlik inancına yönelik her yönetim stratejisi ve tekniği çalışanlara kendilerini daha güçlü hissettirecektir (Conger \& Kanungo, 1988: 473). Bandura (1977) Sosyal Bilişsel Kuramında öz-yeterliğin bireylerin amaçlarına ve istenen sonuçlara başarı ile ulaşacaklarına dair inançlarını ifade ettiğini vurgulamaktadır. Bir diğer ifadeyle öz-yeterliği, "yapabilirimin gücü” olarak ele almak ve basitçe, "bir durum karşısında kişinin ustalaşabileceğine inanmak, kişisel yeterlilik ya da ilgili alanda etkililik anlamına gelen olumlu sonuçlar üretebileceğini düşünmek ve buna inanmak” olarak değerlendirmek mümkündür (Bandura, 1977). 
Özgözgü, S., \& Bektaș, M. (2018). Okul psikolojik danışmanlarında örgütsel özdeşleșme: Psikolojik güçlendirme ve özyeterlik inançlarının rolü. Journal of Human Sciences, 15(4), 1993-2011. doi:10.14687/jhs.v15i4.5372

Bireylerin davranışlarını kestirebilmek için öz-yeterlik inancı önemli bir değişkendir. Örgütteki çalışanlar, kendilerine verilen görevi yerine getirmek amaciyla işin gerektirdiği yetenek ve denetim yeterliğinin kendilerinde var olduğuna inanmaları halinde, verilen görevi seçme konusunda istekleri artar. Öz-yeterlik alg1ları yüksek olan insanlar daha güvenli ve kararlı biçimde hareket ederler (Bandura, 1977) ve işin yapılması için gerekli davranış kalıplarını ortaya koyarlar (Sharp, 2002'den aktaran Korkut \& Babaoğlan, 2012: 270). Öz-yeterlik inançları insanların yaptıkları seçimleri, bir faaliyet için gösterdikleri çabayı, engeller ve güçlükler karşısındaki dayanıklılı̆ı̆nı, düşünce yapısını ve duygularını etkiler (Pajares, 1996). Öz-yeterliği yüksek olan öğretmenler ise mesleklerini daha çok sevecek ve mesleklerine daha fazla bağlı olacaklardır (Tarkın \& Uzuntiryaki, 2012: 33). Bu çalışma bağlamında ele alındığında, okul psikolojik danışmanlarının verdikleri rehberlik ve psikolojik danışma hizmetinin niteliğine etki eden en önemli etkenlerden birisi okul psikolojik danışmanlarının öz-yeterlik algılarıdır (Beutler, Machado \& Neufeldt, 1994'den aktaran Yüksel, Diken, Aksoy \& Karaaslan, 2012). Psikolojik danışmanlardaki danışma öz-yeterliği bir kişinin yakın bir gelecekte bir danışana etkili bir şekilde danışma yapabilme yeterlikleri hakkındaki yargilarıdır (Larson, Suzuki, Gillespie, Potenza, Bechtel \& Toulouse 1992'den aktaran Pamukçu, 2011: 4). Larson'a (1998'den aktaran Pamukçu, 2011: 19) göre danışman öz-yeterlik inancı, ne yapacağını bilme ile eylemi gerçekleştirme arasında aracı rolündedir ve aynı zamanda etkili danışmanın birincil belirleyicisidir. Yapılan araştırmalar, okul psikolojik danışmanlarında; kişilik özellikleri, teorik yönelimler, değerler ve inançlar, stresle baş edebilme stratejileri, iyi oluş düzeyleri gibi etkenlerin, onların psikolojik yardımı etkili bir şekilde sunabilmelerinde önemli rolünün olduğunu göstermektedir. Öz-yeterliği yüksek olan okul psikolojik danışmanlarının başarılı performanslar geliştirerek etkili bir psikolojik danışma yardımı sunabildikleri ve yüksek öz-yeterliğin kariyer hedefleri, mesleğine olan bağlllı̆̆1 ve ilgisini olumlu düzeyde etkilediği bildirilmektedir (Pamukçu \& Demir, 2013).

Alanyazında örgütsel özdeşleşme ile psikolojik güçlendirme (Prati \& Zani, 2013: 853) ve özyeterlik ilişkisi üzerine ilgi sinırlıdır. Bulut (2015), Ertürk (2010), Meydan, Polat ve Burmaoğlu (2010), Prati ve Zani (2013), Taştan (2012), Yarmac1 (2012), Zhu, Sosik, Riggio ve Yang (2012) araştırmalarında, psikolojik güçlendirme ile örgütsel özdeşleşme arasındaki ilişkiyi incelenmiş ve iki değişken arasında pozitif ve anlamlı ilişki bulmuşlardır. Örgütsel özdeşleşme ile örgütsel bağlılık kavramları arasında anlamsal bazı farklılıklar olmasına rağmen, birbirleri ile en fazla ilişkili iki kavram olduğu belirtilmektedir (Çiftçioğlu, 2010; Riketta, 2005). Argyris (1998), işgörenlerin güçlendirilmesi ile örgüte olan bağlllıklarını psikolojik bakımdan ele almıştır. Örgütsel özdeşleşmenin kavramsal yapısı ile örgütsel bağlllık birbirleri ile belirli ölçülerde örtüşmektedir. Ashforth, Harrison ve Corley (2008), Buchanan (1974), Caldwell, Chatman ve O’Reilly (1990), Harris ve Cameron (2005), Johnson, Morgeson ve Hekman (2012), Laschinger, Finegan, Shamtan ve Wilk (2001), O'Reilly ve Chatman'e (1986) göre de özdeşleşme bireyle örgüt arasındaki bağın bileşenlerinden biridir. Psikolojik güçlendirme ve örgütsel bağlllık arasındaki ilişkiyi öğretmenlerin algılarına göre inceleyen araştırmalarda da iki değişken arasında pozitif ve anlamlı ilişkiler bulunmuştur (Bogler \& Somech, 2004). Yine güçlendirmenin boyutları arasında yer alan yeterlik ile de özdeşleşme arasında pozitif ilişki vardır (Polat, Meydan \& Tokmak, 2010).

Çalışanların kurumlarıyla ve örgütleriyle özdeşim kurma düzeyleri arttıkça, kurumlarının ilerlemesi ve karşılaşılan sorunların çözümlenmesi için büyük bir çaba harcayacaklarını söylemek mümkündür (Yıldız, 2013). Bu nedenle, örgütsel özdeşleşmenin sağlanması için çalışanların kendi yeterliklerini nasıl algıladıkları ve bu yeterliklerini harekete geçirecek gücü kendilerinde ne kadar hissettikleri önem taşımaktadır. Bu verilerden hareketle psikolojik güçlendirmenin ve öz-yeterliğin yüksek olmasının örgütsel özdeşleşmeyi pozitif olarak etkileyeceğini söylemek olasıdır. Alan yazında örgütsel özdeşleşme ile genel öz-yeterlik ve psikolojik güçlendirme alg1sını birlikte ele alan araştırmalar sınırlı olmakla birlikte öğretmen algıları üzerinden incelenmesine yönelik bir gereksinim olduğu görülmektedir. Bu açıdan bu araştırma sonunda resmi ve özel eğitim kurumlarında çalş̧an psikolojik danışmanlar tarafindan algılanan örgütsel özdeşleşme, genel öz-yeterlik ve psikolojik 
Özgözgü, S., \& Bektaș, M. (2018). Okul psikolojik danışmanlarında örgütsel özdeşleșme: Psikolojik güçlendirme ve özyeterlik inançlarının rolü. Journal of Human Sciences, 15(4), 1993-2011. doi:10.14687/jhs.v15i4.5372

güçlendirme algıları belirledikten sonra elde edilen bulgulardan yola çıkarak bazı öneriler öne sürülebilecektir.

\section{Araştırmanın Amacı}

Okullardaki PDR hizmetlerinin başlıca yürütücüsü olarak görülen okul psikolojik danışmanlarının kendilerini yeterli görüp görmedikleri, psikolojik olarak güçlü hissedip hissetmedikleri ve buradan hareketle okulları ile özdeşleşme düzeylerinin nasıl etkilendiği bu araştırmanın konusunu oluşturmaktadır. Bu araştırmada Milli Eğitim Bakanlığı (MEB) bünyesindeki resmi ve özel eğitim kurumlarında çalışan okul psikolojik danışmanlarının algılarına dayalı olarak örgütsel özdeşleşme ile öz-yeterlik ve psikolojik güçlendirme arasındaki ilişkinin belirlenmesi amaçlanmıştır. Araştırma problemi “MEB'e bağlı resmi ve özel okullarda çalışan okul psikolojik danışmanlarının algılarına göre öz-yeterlik ve psikolojik güçlendirme örgütsel özdeşleşmeyi yordamakta mıdır?" şeklinde oluşturulmuştur. Bu probleme dayalı olarak araştırmanın alt problemleri aşağıdaki gibi oluşturulmuştur:

1. Okul psikolojik danışmanlarının örgütsel özdeşleşme, genel öz-yeterlik ve psikolojik güçlendirme algıları cinsiyete, yaşa, mezun olunan bölüme, mesleki kıdeme ve eğitim durumuna göre ne düzeydedir?

2. Okul psikolojik danışmanlarının örgütsel özdeşleşme algıları cinsiyete, yaşa, mezun olunan bölüme, mesleki kıdeme ve eğitim durumuna göre farklılık göstermekte midir?

3. Okul psikolojik danışmanlarının genel öz-yeterlik algıları cinsiyete, yaşa, mezun olunan bölüme, mesleki kıdeme ve eğitim durumuna göre farklllık göstermekte midir?

4. Okul psikolojik danışmanlarının psikolojik güçlendirme algıları cinsiyete, yaşa, mezun olunan bölüme, mesleki kıdeme ve eğitim durumuna göre farklılık göstermekte midir?

5. Okul psikolojik danışmanların öz-yeterlik ve psikolojik güçlendirme alg1ları örgütsel özdeşleşme algılarını yordamakta mıdır?

\section{Yöntem}

$\mathrm{Bu}$ araştırmada psikolojik güçlendirme ve genel öz-yeterliğin örgütsel özdeşleşmeyi ne ölçüde yordadığını incelemek amacıyla ilişkisel tarama modeli kullanılmıştır. İlişkisel tarama modeli, iki ve daha fazla sayıdaki değişkenin, birlikte değişim varlığını ve/veya derecesini tespit etmeyi amaçlar (Karasar, 2005: 77). Araştırmada, bağımsız değişkenler olarak öz-yeterlik ve psikolojik güçlendirme, bağımlı değişken olarak ise örgütsel özdeşleşme ele alınmıştır.

\section{Çalışma Grubu}

Araştırma için İzmir ili anakent ilçelerindeki MEB'e bağlı ilk ve orta dereceli resmi ve özel okullarda görev yapan, kolay ulaşılabilir örnekleme yöntemiyle ulaşılan ve araştırmaya katılmayı kabul eden okul psikolojik danışmanlardan veriler toplanmıştır. Araştırma verileri, 2016 y1lında, Rehberlik ve Araştırma Merkezleri tarafindan Psikolojik Danışmanlara yönelik düzenlenen mesleki toplantılarda ve araştırmacılar tarafindan yapılan okul ziyaretlerinde toplanmıştır. Toplamda 374 kişiden geçerli veri elde edilmiştir.

Katılımcıların demografik özelliklerine bakıldı̆̆ında; katılımcıların 253’ü (\%67,6) kadın, 162'si (\%43,3) 31-40 yaş arasında, 276's1 (\%73,8) PDR (Psikolojik Danışma ve Rehberlik), EPH (Eğitimde Psikolojik Hizmetler) ve Psikoloji bölümü mezunu, 119’u (\%31,8) 16-20 yıl arası kıdeme sahip ve 312'si $(\% 83,4)$ lisans mezunudur.

\section{Veri Toplama Araçları}

Araşturma kapsaminda Van Dick, Wagner, Stellmacher ve Christ'in (2004) geliştirdiği "Örgütsel Özdeşleşme Ölçeği"; Spreitzer’in (1995) geliştirdiği ve Sürgevil vd. (2013) tarafindan Türkçe'ye uyarlanan "Psikolojik Güçlendirme Ölçeği”; Yıldırım ve İlhan (2010) tarafindan Türkçeye uyarlanan "Genel Öz Yeterlik Ölçeği” ile araştırmacılar tarafindan geliştirilen ve okul psikolojik danışmanlarının demografik özelliklerini belirten "Kişisel Bilgi Formu” kullanılmıştır.

Örgütsel Özdeşleşme Ölçeği, 7 maddeden oluşan 5’li Likert tipi bir ölçektir. Erel Yetim (2010) tarafindan Türkçe'ye uyarlanan ölçeğin 7 maddeden oluşan kısa versiyonu bir çok çalışmada 
Özgözgü, S., \& Bektaș, M. (2018). Okul psikolojik danışmanlarında örgütsel özdeşleșme: Psikolojik güçlendirme ve özyeterlik inançlarının rolü. Journal of Human Sciences, 15(4), 1993-2011. doi:10.14687/jhs.v15i4.5372

kullanılmıştır (Çırakoğlu, 2010; Köse, 2009; Özgözgü, 2017; Sune, 2016; Yılmaz, 2014). Van Dick vd. (2004), Örgütsel Özdeşleşme Ölçeğinin güvenirliği için Cronbach Alfa değerini 0,81 olarak tespit etmişlerdir. Bu çalş̧mada örgütsel özdeşleşme ölçeği geneli için Cronbach Alfa değeri 0,82 bulunmuş ve Leech, Barrett ve Morgan'a (2005) göre bu sonuç ölçeğin güvenilir olduğunu göstermektedir.

Sürgevil vd. (2013), Spreitzer'e (1995) ait olan Psikolojik Güçlendirme Ölçeğini (Psychological Empowerment Instrument) Türkçe'ye uyarlamıslardır. Sürgevil'in vd. (2013) çalışmasında Psikolojik Güçlendirme Ölçeğine ilişkin yapılan doğrulayıcı faktör analizi sonucunda, ölçeğin orijinal haline uygun bir yap1 sergilediği dört alt boyuttan oluştuğu belirlenmiştir. $\mathrm{Bu}$ araştırmada ise alt boyutlara bakilmamış, toplam puanlar analize dâhil edilmiştir. Psikolojik güçlendirme ölçeği, 5'li Likert tipi biri ölçektir. Bu çalışmada ölçeğin güvenirlik analizinde ölçeğin iç tutarlilık katsayısı (Cronbach Alfa) 0,93 olarak bulunmuş ve bu değere göre ölçek güvenilir olarak kabul edilebilir (Leech vd., 2005).

Genel Öz-yeterlik Ölçeği, 17 maddelik, 5’li Likert tipi bir ölçme aracıdır. Ölçek, bireyin tüm stresli yaşam olaylarına uyum sağlama ve günlük yaşamın zorluklarıyla başa çıkmadaki yeterliği hakkında sahip olduğu zihinsel kestirimini belirlemeyi amaçlamaktadır (Scholz \& Schwarzer, 2005'den aktaran Aypay, 2010: 120). Yıldırım ve İlhan (2010) ölçeğin güvenirlik çalışmasında ölçeğin Cronbach Alfa değerini 0,80; iki yarım güvenirliğini 0,77; test tekrar test güvenirliğinde Pearson Korelasyon değerini ( $\mathrm{r}$ ) 0,69 bulmuştur. Bu çalş̧mada ölçeğin güvenirlik analizinde Cronbach Alfa değeri 0,87 bulunmuştur. Leech ve diğerlerine (2005) göre bu sonuç, ölçeğin güvenilir olduğunun bir kanıtı olarak değerlendirilebilir.

\section{Verilerin Analizi}

Araşturmada grupların alg1 puanlarının değerlendirilmesi için aritmetik ortalama, standart sapma; iki grubun puan ortalamaları arasında farkı test etmek için Bağımsız Gruplar t Testi; ikiden fazla grubun puan ortalamaları arasında farkı test etmek için Tek Yönlü Varyans Analizi (ANOVA); dağılımın homojen olmadığı durumlarda ise ikiden fazla grubun puan ortalamaları arasında fark1 test etmek için Kruskal Wallis testi; değişkenler arasındaki ilişkiyi belirlemek için Pearson Momentler Çarpımı Korelasyon Katsayısı ve değişkenler arasındaki yordama ilişkisini ortaya koymak için ise Hiyerarşik Çoklu Regresyon Analizi kullanılmışır. Araştırmada cinsiyet, yaş, mezun olunan bölüm, mesleki kıdem ve eğitim durumu değişkenlerdeki gruplara göre karşılaştırmalar yapılmıştır. $\mathrm{Bu}$ karşlaştırmalar için anlamlılık düzeyi olarak $\alpha=0,05$ belirlenmiştir.

Aritmetik ortalama puanları yorumlanırken 1,00-1,79 arası kesinlikle katılmıorum, 1,80-2,59 arasi katilmiyorum, 2,60-3,39 arası kısmen kattlyorum, 3,40-4,19 aras1 kat1lyorum, 4,20-5,00 aras1 kesinlikle katllıyorum ifadeleri referans alınmıştır.

\section{Bulgular}

Okul psikolojik danışmanlarının örgütsel özdeşleşme, öz-yeterlik ve psikolojik güçlendirme algılarının cinsiyetlerine göre farklılık analizi sonuçları Tablo 1'de gösterilmiştir.

Tablo 1. Katılımcıların cinsiyetlerine göre örgütsel özdeşleşme, öz-yeterlik ve psikolojik güçlendirme algıları $\mathrm{t}$ testi

\begin{tabular}{llllllll}
\hline Değişken & Cinsiyet & $\mathrm{n}$ & $\bar{x}$ & $\mathrm{SS}$ & $\mathrm{Sd}$ & $\mathrm{t}$ & $\mathrm{p}$ \\
\hline Örgütsel & Kadın & 253 & 3,66 & 0,72 & 372 & \multirow{2}{*}{0,18} & 0,03 \\
Özdeşleşme & Erkek & 121 & 3,83 & 0,68 & & & \\
\hline \multirow{2}{*}{ Öz-yeterlik } & Kadın & 253 & 3,95 & 0,52 & 372 & 0,12 & 0,90 \\
& Erkek & 121 & 3,94 & 0,49 & & & \\
\hline \multirow{2}{*}{ Psikolojik } & Kadın & 253 & 4,08 & 0,56 & 372 & $-0,43$ & 0,67 \\
Güçlendirme & Erkek & 121 & 4,11 & 0,68 & & & \\
\hline
\end{tabular}



yeterlik inançlarının rolü. Journal of Human Sciences, 15(4), 1993-2011. doi:10.14687/jhs.v15i4.5372

Tablo 1'e göre okul psikolojik danışmanlarının öz-yeterlik ve psikolojik güçlendirme algıları cinsiyetlerine göre istatiksel olarak anlamlı farklılık göstermemektedir. Katılımcıların örgütsel Özdeşleşme algılarına bakıldığında erkeklerin ortalama puanları $(\bar{x}=3,83)$, kadınlardan $(\bar{x}=3,66)$ daha yüksektir $(\mathrm{t}=-2,18 ; \mathrm{p}<0,05)$.

Okul psikolojik danışmanlarının yaşlarına göre örgütsel özdeşleşme ve öz-yeterlik algıları aritmetik ortalamaları, standart sapma değerleri ve tek yönlü varyans analizi sonuçları Tablo 2'de gösterilmiştir.

Tablo 2. Katılımcıların yaşlarına göre örgütsel özdeşleşme ve öz-yeterlik algıları tek yönlü varyans analizi

\begin{tabular}{llllllllll}
\hline Değişken & Yaş & $\mathrm{n}$ & $\bar{x}$ & SS & & $\begin{array}{l}\text { Kareler } \\
\text { Toplamı }\end{array}$ & Sd & $\begin{array}{l}\text { Kareler } \\
\text { Ortalaması }\end{array}$ & F \\
\hline \multirow{2}{*}{$\begin{array}{l}\text { Örgütsel } \\
\text { Özdeşleşme }\end{array}$} & 30 yaş ve altı & 64 & 3,48 & 0,76 & GA & 6,95 & 2 & 3,47 & $7,12^{*}$ \\
& 31 -40 yaş & 162 & 3,69 & 0,71 & GI & 180,96 & 371 & 0,49 & \\
& 41 yaş ve üstü & 148 & 3,86 & 0,65 & Toplam & 187,91 & 373 & & \\
\hline \multirow{2}{*}{ Öz-yeterlik } & 30 yaş ve altı & 64 & 3,81 & 0,58 & GA & 2,18 & 2 & 1,09 & $4,31^{*}$ \\
& 31-40 yaş & 162 & 3,92 & 0,49 & GI & 93,94 & 371 & 0,25 & \\
& 41 yaş ve üstü & 148 & 4,03 & 0,49 & Toplam & 96,13 & 373 & & \\
\hline
\end{tabular}

$* \mathrm{p}<0,05$

Tablo 2'de görüldüğü gibi okul psikolojik danışmanlanının örgütsel özdeşleşme, öz-yeterlik ve psikolojik güçlendirme algıları yaş gruplarına göre istatiksel olarak anlamlı farklılık göstermektedir. Farkın hangi gruplar arasında olduğunu belirlemek için yapılan LSD Testi sonucunda 41 yaş ve üstü olanların örgütsel özdeşleşme algıları ( $\bar{x}=3,86), 40$ yaş ve altı olanlara göre $(\mathrm{F}=7,12 ; \mathrm{p}<0,05), 41$ yaş ve üstü olanların öz-yeterlik algıları $(\bar{x}=4,03), 30$ yaş ve altı olanlara göre $(\mathrm{F}=4,31 ; \mathrm{p}<0,05)$ daha yüksektir.

Psikolojik güçlendirme alg1sı varyansının homojen olmadığ1 görüldüğünden gruplar arasında istatiksel olarak anlamlı fark olup olmadığını belirlemek için parametrik olmayan testlerden Kruskal Wallis testi yapılmış ve Tablo 3’te gösterilmiştir.

Tablo 3. Katılımcıların yaşlarına göre psikolojik güçlendirme alg1ları Kruskal Wallis testi

\begin{tabular}{lllllllll}
\hline Değişken & Yaş & $\mathrm{n}$ & $\bar{x}$ & SS & $\begin{array}{l}\text { Sira } \\
\text { Ort. }\end{array}$ & Sd & x2 & $\mathrm{p}$ \\
\hline \multirow{3}{*}{ Psikolojik } & 30 ve altı & 64 & 3,92 & 0,73 & 160,10 & & & \\
Güçlendirme & $31-40$ & 162 & 4,08 & 0,47 & 179,46 & 2 & 10,44 & 0,01 \\
& 41 ve üstü & 148 & 4,16 & 0,65 & 208,15 & & & \\
\hline
\end{tabular}

Tablo 3’te görüldüğü gibi, yaş grupları arasında psikolojik güçlendirme bakımından istatiksel olarak anlamlı fark vardır. Farkın hangi gruplar arasında olduğunu tespit için yapılan Mann-Whitney $\mathrm{U}$ testi sonucunda 41 yaş ve üstü olanların psikolojik güçlendirme algıları, 30 yaş ve altı (U=3612,50; $Z=-2,74 ; p=0,01)$ ile 31-40 yaş arası $(U=10055,50 ; Z=-2,46 ; p=0,01)$ olanlara göre daha yüksektir.

Okul psikolojik danışmanlarının kıdemlerine göre örgütsel özdeşleşme, öz-yeterlik ve psikolojik güçlendirme algılarına ilişkin tek yönlü varyans analizi sonuçlan Tablo 4’te gösterilmiştir. 
Özgözgü, S., \& Bektaş, M. (2018). Okul psikolojik danışmanlarında örgütsel özdeşleşme: Psikolojik güçlendirme ve özyeterlik inançlarının rolü. Journal of Human Sciences, 15(4), 1993-2011. doi:10.14687/jhs.v15i4.5372

Tablo 4. Katılımcıların kıdemlerine göre örgütsel özdeşleşme, öz-yeterlik, psikolojik güçlendirme alg1ları tek yönlü varyans analizi

\begin{tabular}{|c|c|c|c|c|c|c|c|c|c|}
\hline Değişken & Kıdem & $\mathrm{n}$ & $\bar{x}$ & SS & & $\begin{array}{l}\text { Kareler } \\
\text { Toplamı }\end{array}$ & $\mathrm{Sd}$ & $\begin{array}{l}\text { Kareler } \\
\text { Ortalamas1 }\end{array}$ & $\mathrm{F}$ \\
\hline \multirow{5}{*}{$\begin{array}{l}\text { Örgütsel } \\
\text { Özdeşleşme }\end{array}$} & 5 yil ve altı & 38 & 3,50 & 0,90 & & & & \multirow{5}{*}{$\begin{array}{l}1,18 \\
0,50\end{array}$} & \multirow{5}{*}{$2,37^{*}$} \\
\hline & 6-10 yil & 74 & 3,59 & 0,65 & GA & 4,71 & 4 & & \\
\hline & $11-15 \mathrm{v} 1 \mathrm{l}$ & 82 & 3.72 & 0.71 & & 183,20 & 369 & & \\
\hline & $16-20 \mathrm{yll}$ & 119 & 3,80 & 0,70 & Toplam & 187,91 & 373 & & \\
\hline & 21 yıl ve üstü & 61 & 3,85 & 0,64 & & & & & \\
\hline \multirow{5}{*}{ Öz-yeterlik } & 5 y1l ve alt1 & 38 & 3,88 & 0,66 & & & & \multirow{5}{*}{$\begin{array}{l}0,37 \\
0,26\end{array}$} & \multirow{5}{*}{1,46} \\
\hline & 6-10 y1l & 74 & 3,86 & 0,45 & GA & 1,49 & 4 & & \\
\hline & $11-15$ vil & 82 & 3.92 & 0.48 & Gİ & 94,63 & 369 & & \\
\hline & $16-20 \mathrm{yll}$ & 119 & 3,98 & 0,48 & Toplam & 96,13 & 373 & & \\
\hline & 21 y1l ve üstü & 61 & 4,04 & 0,55 & & & & & \\
\hline \multirow{5}{*}{$\begin{array}{l}\text { Psikolojik } \\
\text { Güçlendirme }\end{array}$} & 5 yil ve altı & 38 & 3,95 & 0,73 & \multirow{5}{*}{$\begin{array}{l}\text { GA } \\
\text { GI } \\
\text { Toplam }\end{array}$} & \multirow{5}{*}{$\begin{array}{l}5,39 \\
128,53 \\
133,91\end{array}$} & & \multirow{5}{*}{$\begin{array}{l}1,35 \\
0,35\end{array}$} & \multirow{5}{*}{$3,87^{* *}$} \\
\hline & 6-10 yil & 74 & 4,00 & 0,53 & & & 4 & & \\
\hline & $11-15$ yll & 82 & 4,02 & 0,60 & & & 369 & & \\
\hline & $16-20 \mathrm{y} 1 \mathrm{l}$ & 119 & 4,11 & 0,56 & & & 373 & & \\
\hline & 21 vil ve üstü & 61 & 4,33 & 0,60 & & & & & \\
\hline
\end{tabular}

Tablo 4’te görüldüğü gibi okul psikolojik danışmanlarının örgütsel özdeşleşme ve psikolojik güçlendirme algıları kıdemlerine göre istatiksel olarak anlamlı farklılık göstermektedir. Farkın hangi gruplar arasında olduğunu belirlemek için yapılan LSD Testi sonucu 16 yıl ve üstü kıdemi olanların örgütsel özdeşleşme algıları kıdemi 10 yıl ve altı olanlara göre daha yüksektir $(F=2,37 ; p<0,05)$. Ayrıca psikolojik güçlendirme algılarına bakıldığında 21 yıl ve üstü kıdeme sahip okul psikolojik danışmanlarının ( $\bar{x}=4,33), 20$ yıl ve altı kıdeme sahip olanlara göre psikolojik güçlendirme algıları daha yüksektir $(\mathrm{F}=3,87 ; \mathrm{p}<0,01)$. Öte yandan Tablo 4 incelendiğinde okul psikolojik danışmanlarının öz-yeterlik alg1ları kıdemlerine göre istatiksel olarak anlamlı farklılık bulunmamıştır.

Okul psikolojik danışmanlarının mezun oldukları bölüme göre öz-yeterlik, psikolojik güçlendirme ve örgütsel özdeşleşme algilarına ait t testi sonuçları Tablo 5’te gösterilmiştir.

Tablo 5. Katılımcıların mezun oldukları bölüme göre örgütsel özdeşleşme, öz-yeterlik, psikolojik güçlendirme alg1ları t testi

\begin{tabular}{|c|c|c|c|c|c|c|c|}
\hline Değişken & Bölüm & $\mathrm{n}$ & $\bar{x}$ & SS & $\mathrm{Sd}$ & $\mathrm{t}$ & $\mathrm{p}$ \\
\hline \multirow{2}{*}{$\begin{array}{l}\text { Örgütsel } \\
\text { Özdeşleşme }\end{array}$} & PDR, EPH ve Psikoloji & 276 & 3,66 & 0,72 & \multirow{2}{*}{372} & \multirow{2}{*}{$-2,63$} & \multirow{2}{*}{0,01} \\
\hline & Diğer & 98 & 3,88 & 0,67 & & & \\
\hline \multirow{2}{*}{ Öz-yeterlik } & PDR, EPH ve Psikoloji & 276 & 3,92 & 0,50 & \multirow{2}{*}{372} & \multirow{2}{*}{$-1,34$} & \multirow{2}{*}{0,18} \\
\hline & Diğer & 98 & 4,00 & 0,52 & & & \\
\hline \multirow{2}{*}{$\begin{array}{l}\text { Psikolojik } \\
\text { Güçlendirme }\end{array}$} & PDR, EPH ve Psikoloji & 276 & 4,10 & 0,59 & \multirow{2}{*}{372} & \multirow{2}{*}{0,66} & \multirow{2}{*}{0,51} \\
\hline & Diğer & 98 & 4,05 & 0,62 & & & \\
\hline
\end{tabular}

Tablo 5’e göre psikolojik danışmanların örgütsel özdeşleşme algılarına bakıldığında diğer bölüm mezunlarının $(\bar{x}=3,88)$, PDR, EPH ve Psikoloji mezunlanına göre $(\bar{x}=3,66)$ örgütsel özdeşleşme algilarının daha yüksek olduğu görülmektedir $(\mathrm{t}=-2,63 ; \mathrm{p}<0,05)$. Ancak psikolojik 
Özgözgü, S., \& Bektaş, M. (2018). Okul psikolojik danışmanlarında örgütsel özdeşleşme: Psikolojik güçlendirme ve özyeterlik inançlarının rolü. Journal of Human Sciences, 15(4), 1993-2011. doi:10.14687/jhs.v15i4.5372

danışmanların öz-yeterlik ve psikolojik güçlendirme algıları mezun oldukları bölüme göre istatiksel olarak anlamlı bir farklılık göstermemektedir.

Okul psikolojik danışmanlarının eğitim durumlarına göre örgütsel özdeşleşme, öz-yeterlik ve psikolojik güçlendirme algılarına ilişkin t testi sonuçları Tablo 6'da gösterilmiştir.

Tablo 6. Katılımcıların eğitim durumuna göre örgütsel özdeşleşme, öz-yeterlik ve psikolojik güçlendirme algiları $\mathrm{t}$ testi

\begin{tabular}{llllllll}
\hline Değişken & Bölüm & $\mathrm{n}$ & $\bar{x}$ & $\mathrm{SS}$ & $\mathrm{Sd}$ & $\mathrm{t}$ & $\mathrm{p}$ \\
\hline Örgütsel & Lisans & 312 & 3,75 & 0,70 & \multirow{2}{*}{372} & 1,61 & 0,11 \\
Özdeşleşme & Lisansüstü & 62 & 3,59 & 0,77 & & & \\
\hline \multirow{2}{*}{ Öz-yeterlik } & Lisans & 312 & 3,94 & 0,49 & \multirow{2}{*}{372} & $-0,62$ & 0,54 \\
& Lisansüstü & 62 & 3,98 & 0,59 & & & \\
\hline Psikolojik & Lisans & 312 & 4,08 & 0,60 & \multirow{2}{*}{372} & $-0,46$ & 0,64 \\
Güçlendirme & Lisansüstü & 62 & 4,11 & 0,58 & & & \\
\hline
\end{tabular}

Tablo 6’ya göre psikolojik danışmanların eğitim durumlarına göre örgütsel özdeşleşme, özyeterlik ve psikolojik güçlendirme algıları arasında istatiksel olarak anlamlı fark yoktur.

Katılımcıların algılarına göre örgütsel özdeşleşme, öz-yeterlik ve psikolojik güçlendirme değişkenlerine ilişkin aritmetik ortalama, standart sapma ve değişkenler arasındaki korelasyon değerleri Tablo 7'de gösterilmiştir.

Tablo 7. Örgütsel özdeşleşme, öz-yeterlik ve psikolojik güçlendirme aritmetik ortalama, standart sapma ve korelasyon değerleri

\begin{tabular}{lccccc}
\hline Değişken & $\bar{x}$ & SS & Örgütsel Özdeşleşme & Öz-yeterlik & $\begin{array}{l}\text { Psikolojik } \\
\text { Güçlendirme }\end{array}$ \\
\hline $\begin{array}{l}\text { Örgütsel } \\
\text { Özdeşleşme }\end{array}$ & 3,72 & 0,71 & 1,00 & $0,43^{*}$ & $0,38^{*}$ \\
$\begin{array}{l}\text { Öz-yeterlik } \\
\text { Psikolojik }\end{array}$ & 3,94 & 0,51 & & 1,00 & $0,45^{*}$ \\
Güçlendirme & 4,09 & 0,60 & & & 1,00 \\
\hline${ }^{*}<<0,001$ & & & &
\end{tabular}

Tablo 7'ye göre, katılımcıların örgütsel özdeşleşme $(\bar{x}=3,72)$, öz-yeterlik $(\bar{x}=3,94)$ ve psikolojik güçlendirme $(\bar{x}=4,09)$ algıları beşli dereceleme üzerinden "katıllyorum" düzeyindedir. Değişkenler arasındaki korelasyon değerlerine bakıldığında örgütsel özdeşleşme ile öz-yeterlik arasında $(r=0,43 ; p=0,00)$, örgütsel özdeşleşme ile psikolojik güçlendirme arasında $(r=0,38 ; p=0,00)$, öz-yeterlik ile psikolojik güçlendirme arasında $(\mathrm{r}=0,45 ; \mathrm{p}=0,00)$ orta düzeyde pozitif ve anlamlı ilişki olduğu görülmektedir.

Okul psikolojik danışmanlarının algılarına göre örgütsel özdeşleşmenin yordanmasında psikolojik güçlendirme ve öz-yeterlikten oluşan modelin regresyon analizi sonuçlan Tablo 8'de gösterilmiştir. 
Özgözgü, S., \& Bektaș, M. (2018). Okul psikolojik danışmanlarında örgütsel özdeşleșme: Psikolojik güçlendirme ve özyeterlik inançlarının rolü. Journal of Human Sciences, 15(4), 1993-2011. doi:10.14687/jhs.v15i4.5372

Tablo 8. Örgütsel özdeşleşmenin yordanmasında psikolojik güçlendirme ve öz-yeterliğe ilişkin hiyerarşik çoklu regresyon analizi

\begin{tabular}{lllllll}
\hline Değişkenler & $\mathrm{B}$ & $\mathrm{SE}$ & $\beta$ & $\mathrm{t}$ & $\Delta \mathrm{R}^{2}$ & $\mathrm{~F}$ \\
\hline Sabit & 1,36 & 0,26 & & $5,23^{*}$ & & \\
Öz-yeterlik & 0,60 & 0,07 & 0,43 & $9,12^{*}$ & & $83,14^{*}$ \\
\hline Sabit & 0,81 & 0,28 & & $2,88^{*}$ & & \\
Öz-yeterlik & 0,45 & 0,07 & 0,32 & $6,31^{*}$ & 0,22 & $54,30^{*}$ \\
Psikolojik Güçlendirme & 0,28 & 0,06 & 0,23 & $4,58^{*}$ & & \\
\hline
\end{tabular}

${ }^{*} \mathrm{p}<0,001$

Tablo 8'e göre öz-yeterlik tek başına örgütsel özdeşleşmeyi anlamlı derecede yordamaktadır $\left(\mathrm{F}_{(1,372)}=83,14 ; \mathrm{p}=0,00 ; \Delta \mathrm{R}^{2}=0,18\right)$. Buna göre okul psikolojik danışmanlarının öz-yeterlik algıları örgütsel özdeşleşme algılarının \%18’ini açıklamaktadır. Modele öz-yeterliğin yanında psikolojik güçlendirme de eklendiğinde örgütsel özdeşleşme algılarının anlamlı şekilde yordandığ1 görülmektedir $\left(\mathrm{F}_{(2,371)}=54,30 ; \mathrm{p}=0,00 ; \Delta \mathrm{R}^{2}=0,22\right)$. Hiyerarşik çoklu regresyonun ikinci modelindeki değişken kombinasyonunu oluşturan öz-yeterlik ve psikolojik güçlendirme algıları, örgütsel özdeşleşme varyansının \%22'sini açıklamaktadır. Bu durumda okul psikolojik danışmanlarının örgütsel özdeşleşme algiları ile ilgili yordama düzeyi sadece öz-yeterlikte \%18 iken, buna psikolojik güçlendirme de eklendiğinde \%4'lük bir artşsla \%22'ye yükselmiştir. Hem öz-yeterlik hem de psikolojik güçlendirme örgütsel özdeşleşmenin yordanmasına anlamlı katkı yapmışlardır.

\section{Sonuç, Tartışma ve Öneriler}

Bu araştırmada, resmi ve özel okullarda görev yapan psikolojik danışmanların genel özyeterlik, psikolojik güçlendirme ve örgütsel özdeşleşme algıları ve genel öz-yeterlik ile psikolojik güçlendirme algılarının örgütsel özdeşleşmeyi yordayıp yordamadığı incelenmiştir.

Araştırmaya katılan psikolojik danışmanların genel öz-yeterlik algılarında; cinsiyet, mezun olunan bölüm, öğretmenlik mesleğindeki kıdem ve eğitim durumları istatiksel olarak anlamlı fark yaratmamıştır. Araştırmaya katılan okul psikolojik danışmanlarının genel öz-yeterlik algılarında cinsiyete göre anlamlı bir farklılı̆̆ın olmadığı görülmüştür. Alan yazın incelendiğinde bu bulguyu destekleyecek şekilde Yiyit (2001), Coşkun ve Ilgar (2004), Güven (2005), Uslu ve Arı (2005), Çimen (2007) ve Aksoy ve Diken (2009) tarafindan yapılan çalışmalarda da cinsiyet grupları arasında anlamlı bir fark bulunamamıştır. Buna karşılık, Çapri ve Çelikali (2008) ve Ekici (2006) tarafından öğretmenlerle yapılan çalışmada kadın katılımcıların öz-yeterlik inançlarının erkeklerden daha yüksek olduğu; Akbulut (2006), Savran ve Çakıroğlu'nun (2003) yaptıkları çalışmada ise öz-yeterlik inançları bakımından erkeklerin öz-yeterlik inançlarının kadınlardan daha yüksek olduğunu tespit etmişlerdir. Tüm bu sonuçlar birlikte değerlendirildiğinde cinsiyete ilişkin bulgular dikkat çekicidir. Öte yandan Bandura'ya (2002) göre cinsiyete göre öz yeterlik inançları, kültürlere göre farklılık gösterebilmektedir. Denizoğlu'na (2008) göre, kadınlar ve erkekler arasında, ailedeki yaşantıda, okul ve iş yaşamında görülebilen eşitsizlik, eski zamanlara kıyasla giderek daha az yaşanmakla birlikte; kadınlar son zamanlarda sosyal yaşamda daha aktif hale gelmekte ve iş yaşamlarında erkekler ile aralarındaki farklılıklar gün geçtikçe daha fazla kapanmaktadır. Bununla birlikte yaş durumuna bakıldığında 41 yaş ve üstü olanların 30 yaş ve altı olanlara göre genel öz-yeterlik algıları daha yüksektir. Benzer bir biçimde, Yaka (2005), okul psikolojik danışmanlanının temel psikolojik danışma becerilerine ilişkin yeterlik düzeylerini ele aldığı araştırmasında, kadınların yeterlik algılarının erkeklerden; PDR ve Psikoloji mezunlarının diğer bölüm mezunlarından daha yüksek olduğu, çalışma süresinde ise anlamlı fark olmadığı görülmüştür. Buradan hareketle kadınlar ve erkeklerin 
Özgözgü, S., \& Bektaş, M. (2018). Okul psikolojik danışmanlarında örgütsel özdeşleşme: Psikolojik güçlendirme ve özyeterlik inançlarının rolü. Journal of Human Sciences, 15(4), 1993-2011. doi:10.14687/jhs.v15i4.5372

farklı alanlarda ve farklı biçimlerde öz-yeterliğe ulaşabildikleri, aldıkları lisans eğitimleri sonucunda da cinsiyetlerinden bağımsız olarak kendilerinden beklenen görev ve sorumlulukları yerine getirebileceklerine ve karşılaştıkları zorlukların üstesinden gelebileceklerine yönelik inanca sahip olmaları bu durumun bir açıklaması olarak görülebilir. Ayrıca, artan yaşla birlikte kişilerin deneyimleri, sorun çözebilme kapasiteleri, hatalarından ve başkalarının hatalarından dersler çıkabilmeleri ve olayları daha geniş bir açıdan bakabilmeleri mümkün olabilmektedir. Bu nedenle de 41 yaş ve üstü katılımcıların öz-yeterlik algılarının daha yüksek olması beklenen bir durum olarak kabul edilebilir.

Katılımcılar genel öz-yeterlik ölçeği maddelerine "katılıyorum" düzeyinde yanıtlamışlardır. Uslu ve Arı'nın (2005) yaptıkları çalışmada ise okul psikolojik danışmanlarının danışma becerilerini "iyi” düzeyde gördükleri bulunmuştur. Aynı çalışmada okul psikolojik danışmanlarının psikolojik danışma becerileri ile ilgili algılarında kıdemin fark yaratmadığı görülmüsstür. Öte yandan Özgün'ün (2007) çalışmasında da bu çalışmanın bulgularına paralel bir şekilde okul psikolojik danışmanlarının öz yeterlik algıları ile mezun oldukları lisans programları arasında anlamlı bir ilişki tespit edilmediği görülmüştür. Katılımcıların genel olarak kendilerini yaptkkları işle ilgili olarak yeterli görmeleri aldıkları temel lisans eğitimi, katıldıkları mesleki hizmet içi eğitim çalışmaları ve meslektaşlarından öğrenme olanaklarına sahip olmaları ile ilişkili olabilir.

Katılımcıların psikolojik güçlendirme algilarına bakıldığında; cinsiyet, mezun olunan bölüm ve eğitim durumu değişkenlerine göre anlamlı fark bulunmazken, yaş gruplarında 41 yaş ve üstü olanların 40 yaş ve altına göre, 21 yıl ve üstü kıdeme sahip olanların ise 20 yıl ve altına göre psikolojik güçlendirme puan ortalamalarının daha yüksek olduğu belirlenmiştir. Hem kıdem hem de yaş durumunda çıkan istatistiksel fark birbirini destekler niteliktedir. Yaş ve kıdem yükseldikçe katılımcıların psikolojik olarak kendilerini daha güçlü hissettikleri görülmektedir. Durukan, Akyürek ve Coşkun'un (2010) hem yaş hem de kıdem ile ilgili bulguları, bu araştırmadaki bulgular ile kısmen benzerlik göstermektedir. Solansky (2014) deneyimin psikolojik güçlendirme ile pozitif bir ilişkisi olduğunu, deneyim arttıkça psikolojik güçlendirme algısının da yükseldiğini belirtmiştir. Yine Solansky (2014) eğitim durumunun psikolojik güçlendirme ile pozitif ilişkisi olduğunu belirtmiştir. $\mathrm{Bu}$ araştırmada ise eğitim durumu katıllımcıların alg1 düzeylerinde bir fark yaratmamıştır. Araştırmada ayrıca cinsiyet değişkenine göre okul psikolojik danışmanlarının psikolojik güçlendirme algıları arasında anlamlı bir farklılık bulunmamıştır. Durmaz'ın (2011) çalışmasında psikolojik güçlendirme algısında cinsiyete göre anlamlı bir farklılık yokken, Altınkurt, Türkkaş Anasız ve Ekinci'nin (2016) çalışmasında ise cinsiyete göre anlamlı bir farklılaşma tespit edilmiştir. Ayrıca katılımcılar psikolojik güçlendirme maddelerine "katıllyorum" düzeyinde yanıt vermişlerdir. $\mathrm{Bu}$ sonuç, katılımcıların kendilerini psikolojik olarak güçlü hissettikleri şeklinde yorumlanabilir.

Araştırmada psikolojik danışmanların örgütsel özdeşleşme algıları cinsiyet değişkenine göre incelendiğinde; erkek katılımcıların örgütsel özdeşleşme alg1ları, kadınlara kıyasla daha yüksektir. Akpınar (2014), İşcan (2006) ve Taşlıyan, Hırlak ve Çiftçi (2016) tarafından yapılan çalışmalarda, erkek katılımcıların örgütsel özdeşleşme düzeylerinin kadın katılımcılara oranla daha yüksek olduğu tespit edilmiştir. Öte yandan Erdoğdu ve Aydındağ’’n (2013), Çanak ve Avcı'nın (2016) çalışmasında ise kadın öğretmenlerin örgütsel özdeşleşme alg1 düzeyi erkek öğretmenlere göre daha yüksek bulunmuştur. Bu bulguların aksine; Tüzün Kalemci (2006) ve Polat'ın (2009) çalışmalarında ise cinsiyetler arasında anlamlı bir farklllık yoktur. Araştırmada erkek öğretmenlerin örgütsel özdeşleşme algılarının kadınlara kıyasla daha yüksek olmasını toplumsal cinsiyet rolleri ile açıklamak mümkündür. Erkekten işine bağlı, işte başarll, yetkin olmaları beklenirken kadınlardan ise ilk olarak evlerine ve çocuklarına bağlı olmaları beklenmektedir. Hatta mesleki yönelimler arasındaki farklılıklar incelendiğinde her ne kadar neredeyse eşit sayıda kadın ve erkek öğretmenler varsa da öğretmenlik daha çok bir "kadın" mesleği olarak algılanmaktadır. Evine ve çocuklarına daha fazla zaman ayırabilmesi için kadının işten sonra hemen evine dönmesi beklenmektedir. İși ile daha fazla vakit geçiren kadınların ise aileyi önemsemedikleri şeklinde suçlamalara maruz kaldıkları bilinmektedir. Bu durum erkeğin daha fazla işine ve kadının ise daha çok evine yatırım yapmasına ve böylelikle de farklı alanlarla özdeşleşmelerine yol açmış olabilir. 
Özgözgü, S., \& Bektaş, M. (2018). Okul psikolojik danışmanlarında örgütsel özdeşleşme: Psikolojik güçlendirme ve özyeterlik inançlarının rolü. Journal of Human Sciences, 15(4), 1993-2011. doi:10.14687/jhs.v15i4.5372

Araştırmada okul psikolojik danışmanlarının örgütsel özdeşleşme algılarına bakıldığında, yaşları ve kıdemleri arasında anlamlı bir farklılık olduğu belirlenmiştir. Yaş durumuna göre, 41 yaş ve üstü olanların daha genç olanlardan; 16 yıl ve üstü kıdeme sahip olanların 10 yıl ve altı kıdeme sahip olanlardan daha yüksek özdeşleşme algisı olduğu görülmektedir. Polat'ın (2009) çalışmasında örgütsel özdeşleşme ve iş yerinde çalışma süresine göre anlamlı bir farkllılı bulunmamasına karşılık; katılımcıların yaş grupları açısından anlamlı bir ilisski bulunmuştur. Buna karşılık; Tüzün ve Kalemci (2006) tarafindan gerçekleştirilen çalısmada ise yaşa ve kurumda çalışma süresine göre anlamlı bir farklılık yoktur. Kıdem artışı aynı zamanda yaşam sürecinde temel gelişim hedeflerine ulaşılması ile de ilisskili olabilir. Mesleğinin görece daha başında olan kattlımcıların aynı zamanda, gençlikten yeni çıktıkları, kendi hayatlarını planladıkları, kendilerine bir aile kurmaya çalışıkları, ekonomik olarak güçlenmeye çalıştıkları ve doğan çocuklarının ilk yıllarını yaşadıkları bir gerçektir. Üniversite bitirme yaşını ortalama 22-23 olarak kabul edildiğinde meslekteki ilk on y1l 32-33-34 yıllarına denk gelebilmektedir. Bu süreçte katılımcıların aynı zamanda mesleği de yeni öğrendikleri, yoğun bir şekilde çatışma yaşadıkları bir süreçtir. Yaşanan çatışmaların yönetilmesi, mevcut engellerin aşılması için de bir süreye ihtiyaç bulunmaktadır. Oysa ki kıdemin artması aynı zamanda yaşamda bir rutinleşmeye, bir olgunlaşmaya da denk gelmektedir. Bu nedenle de kıdem artışı katılımcıların işlerine daha fazla yatırım yaptıkları ve yaptıkları yatırımların sonuçlarını almaya başladıkları şeklinde de yorumlanabilir.

Araştırmada elde edilen bir başka bulguya göre diğer bölüm mezunlarının PDR, EPH ve Psikoloji bölümlerinden mezun olan katıllmcılara göre okullarıla daha fazla özdeşleştikleri söylenebilir. Bu durumu öz-yeterlik inancı ile açıklamak mümkündür. Alan mezunlarının aldıkları lisans eğitimlerinin doğası gereği bireysel ve grupla psikolojik danışma, kriz ve travmayla başa çıkma gibi spesifik alanlarda donanımlı olmaları beklenmektedir. Bununla birlikte, okullarda rehberliğin kapsamı içerisinde yer alan bilgi verme, yöneltme, verimli ders çalışma, alan seçme, bir üst eğitim kurumuna yönlendirme vb. çalışmalar da önemli bir yer tutmaktadır. Rehberlik Servisinin aktif olmamasının ve rehberlik servisinin bir disiplin yeri olarak görülmesinin nedenleri arasında psikolojik danışmanların kişilik özellikleri, mesleki yeterliliği, iş doyumu, rehberlik etkinliklerini yürütürken zamanını ve enerjisini etkin kullanamaması, mesleki eğilimi, idari görevlere ilgi duyması gibi sorunlar bulunmaktadır. Lisans eğitiminin mezunlarına kazandırmaya hedeflediği bilgi ve becerilerin sahaya aktarılmasında birtakım sıkıntılar olduğu artık bilinen bir problemdir (Donat Bacıŏ̆lu, Kocabıyık ve Malkoç, 2017: 55). Ayrıca yapılan araştırmalarda okullarda yürütülen rehberlik faaliyetleri sırasıyla; bireyi tanıma, bilgi toplama ve sunma, yöneltme ve yerleştirme, araşturma-değerlendirme ve konsültasyon hizmetleri olarak belirtilmiş, bu hizmetler arasında psikolojik danışma hizmetlerine yer verilmediği ise daha fazla vurgulanmıştır. Donat Bacıoğlu'nun (2014'den akt. Donat Bacıoğlu vd., 2017: 53) yapmış olduğu araşturma sonucunda da, alanda çalışırken lisans eğitiminin teoride yeterli, pratikte yetersiz kaldığı; süpervizyon ihtiyacının alanda çalışırken de devam ettiği saptanmıştır. Donat Bacıŏ̆lu vd. 'nin (2017: 53) aktardığına göre Tuzgöl Dost ve Keklik (2012) araştırmalarında, alan eğitiminin mezunlarına kazandırmaya çalıştığı bilgi ve becerilerde önemli aksamaların olduğu, mezunların yeterli derecede uygulama alanlarına ve MEB sistemine aşina olmadıkları ortaya çıkmıştır. Ayrıca, Korkut Owen ve Owen'ın (2008) yaptıkları araştırmanın sonucunda da okul psikolojik danışmanlarının zamanlarının çoğunu yönetsel işlere ayırdıkları buna karşılık bireysel psikolojik danışma hizmetlerine daha az zaman ayırdıkları bulunmuştur. Bir başka ifadeyle, okul psikolojik danışmanlarının gerçek zaman kullanımı ile ideal zaman kullanımları arasında anlamlı bir farklılık olduğu tespit edilmiştir. Görevleri dışında kalan işleri yerine getirmek zorunda bırakılan okul psikolojik danışmanları, yeterli seviyede Psikolojik Danışma ve Rehberlik hizmeti veremediklerini düşünmektedirler.

$\mathrm{Bu}$ araştırmada yaşları ve kıdemleri yüksek olan okul psikolojik danışmanlarına kıyasla, daha genç olan ve kıdemi daha az olan okul psikolojik danışmanlarının öz-yeterlik, psikolojik güçlendirme ve örgütsel özdeşleşme algıları daha düşük çıkmıştır. Dolayısıyla mesleğe yeni başlamış okul psikolojik danışmanlanının düzenli aralıklarla ve ihtiyaç duyulan konularda hizmet içi eğitim almalarının sağlanması, daha kıdemli olan meslektaşları tarafından mentörlük desteğinin verilmesi ve 
Özgözgü, S., \& Bektaş, M. (2018). Okul psikolojik danışmanlarında örgütsel özdeşleşme: Psikolojik güçlendirme ve özyeterlik inançlarının rolü. Journal of Human Sciences, 15(4), 1993-2011. doi:10.14687/jhs.v15i4.5372

kurum içi özdeşleşmelerini arttıracak çalışmaların planlanması ve uygulanması, okul psikolojik danışmanlarının psikolojik olarak kendilerini güçlü hissetmelerine katkı sağlayabileceği gibi aynı zamanda okullariyla özdeşleşmelerini de artturabilir.

Araştırmada okul psikolojik danışmanlarının genel öz-yeterlik, psikolojik güçlendirme ve örgütsel özdeşleşme algıları arasında anlamlı ilişkiler bulunmuştur. Bulut (2015), Ertürk (2010), Meydan vd. (2010), Prati ve Zani (2013), Taştan (2012), Yarmac1 (2012), Zhu vd. (2012) yaptkklar1 çalışmalarda da psikolojik güçlendirme ve örgütsel özdeşleşme algıları arasında anlamlı ilişki bulunmuştur. Araştırmada ayrıca bağımsız değişkenlerin örgütsel özdeşleşme algısını yordayıp yordamadıklanına ilişkin analiz yapılmıstır. Öncelikle genel öz-yeterlik algısının örgütsel özdeşleşme algısını yordama düzeyine bakılmış, daha sonra genel öz-yeterlik ve psikolojik güçlendirme beraber örgütsel özdeşleşmeyi yordamasına ilişkin bulgular karşılaştırılmıştır. Buna göre genel öz-yeterlik tek başına örgütsel özdeşleşmeyi anlamlı şekilde yordarken, genel öz-yeterlik yanına psikolojik güçlendirme eklendiğinde yordama gücü anlamlı şekilde yükselmiştir. Bu sonuca göre okul psikolojik danışmanlarının okulları ile bağlarını güçlendirmelerine, kendilerini okulları ile özdeş görmelerine, öz-yeterlik ve psikolojik güçlendirme algıları olumlu yönde etki etmektedir. Bir diğer ifadeyle kendilerini başta işinde olmak üzere çeşitli alanlarda yeterli hissedenler psikolojik olarak sorunlar karşısında daha dayanıklı görebilmekte, engellemeler, çatışmalar ve sıkıntılar karşısında başta kendi yeterliliklerine ve sorun çözebilme kapasitelerine sonra da çevrelerindeki olumlu desteklerden ve firsatlardan yararlanabilme gücünü kendilerinde hissedebilmektedir. Kendilerini psikolojik olarak güçlü ve yeterli hissedenler işte kendilerini daha başarılı hissedebilir, iş arkadaşlarıyla, çalıştığı kurumla daha güçlü bağlar kurabilir, kendisini oranın etkili ve değerli bir parçası olarak görebilir.

Okul psikolojik danışmanlarının okulla özdeşleşmelerini sağlamak için genel öz-yeterliklerini yükseltmek ve psikolojik olarak güçlendirmek gerekmektedir. Çalışanların etkililiğini ve dolayısıyla örgütün başarısını sağlamak, ancak örgütte güçlendirilmiş çalışanların varlı̆gı ile mümkündür. Güçlendirilmiş ast, sorumluluk almak isteyen, sağduyulu, risklere girebilen, karar verme sürecine katılan, fikirler üreten, öğrenmek, bilgi ve becerilerini geliştirmek isteyen, örgüte katkısına ve kendi potansiyeline inanan bireydir (Özarallı, 1998). Çalışanların psikolojik güçlendirme algılarını yükseltmek için iş yeri arkadaşlıklarının ve örgütsel iletişimin iyileştirilip arttırılması (Çalışkan, 2011: 77) önerilebilir.

Okul psikolojik danışmanlarının okul rehberlik hizmetlerini yürütürken en çok işbirliği içinde oldukları kişiler; okulun yöneticileri, okul öğretmenleri, öğrenci velileri ve görevlerini yerine getirilmelerine yardımcı olan diğer çalışanlardır. Fakat bu sayılanlar içerisinde psikolojik danışmanın okulda rehberlik hizmetleri çerçevesinde gerçekleştireceği rehberlik etkinliklerini etkileyenler arasında en önemli kişiler okuldaki yöneticilerdir (Korkut Owen \& Owen, 2008). Bununla birlikte bazı çalışmalarda okul müdürünün rehberlik hizmetleri ile ilgili bilgi ve anlayışının yetersiz olması, bundan kaynaklı olarak; rehberlik hizmetlerine olan ilgisizliği, gereken desteği vermemesi, psikolojik danışmanın mevzuatta belirlenen görevleri ve sorumluluklarını bilmemesi, rehberlik hizmetleri servisinin okul için taşıdığı önemi kavrayamaması, psikolojik danışmandan görev tanımının dışındaki işlerin yapılmasını istemesi, psikolojik danışmandan beklenti ve isteklerin fazla olmasına ilişkin sonuçlar ortaya konulmuştur (Donat Bacioğlu vd., 2017). Bu bağlamda okuldaki yöneticilerin liderlik davranışları öğretmenlerin işleri ile ilgili bireysel ve örgütsel alg1larını etkilemektedir (Özgözgü, 2017; Özgözgü \& Altunay, 2016). Okul liderinin davranışları öğretmenlerin psikolojik güçlendirmeleri için etkili bir değişkendir. Arslantaş’a (2007) ve Konczak, Stelly ve Trusty'e (2000) göre güçlendirici lider davranışı psikolojik güçlendirme üzerinde etkiye sahiptir. Arslantaş'ın (2007) araştırmasına göre lider, yetki ve sorumluluk verdiğinde, "beceri geliştirme" ve "yenilikçi performans için koçluk" yaptığında çalışanların psikolojik güçlendirme algılarını yükseltir. Psikolojik güçlendirme yanında öğretmenlerin genel öz-yeterlik algılarının yükseltilmesi okulla özdeşleşmeleri için önemli bir etkendir. Bu anlamda liderin davranışları öne çıkmaktadır. Dönüşümcü liderlik, çalışanlarda öz-yeterlik inancını arttırdığı gibi çalışanın örgüte olan bağını da güçlendirir (Givens, 2008). Okul müdürünün dönüşümcü liderlik ile ilgili davranışlanı arasında; bireysel etkileme ve 
Özgözgü, S., \& Bektaș, M. (2018). Okul psikolojik danışmanlarında örgütsel özdeşleșme: Psikolojik güçlendirme ve özyeterlik inançlarının rolü. Journal of Human Sciences, 15(4), 1993-2011. doi:10.14687/jhs.v15i4.5372

esinlendirme, çalışanların kişisel gereksinimlerini karşılama, çalışanları birtakım ortak hedefler ve vizyon çevresinde toplama, çalışanların iş birliği yapabilecekleri ortamı oluşturma sayılabilir (Kurt, 2012: 213).

Örgütleriyle özdeşleşen ya da bir diğer ifadeyle örgütle kendini bütünleştiren okul psikolojik danışmanlarının kendilerine düşen görevi hakkıyla yerine getireceklerine dair öz-yeterlik inançlarının yüksek olacağını söylemek mümkündür. Görevini yerine getirirken karşılaşlabilecek sorunlar karşısında kendini güçlü hisseden, bu zorlukların aşılması konusunda kurum içi ve kurum dışı destek ve süpervizyon alan, diğer öğretmenler ve yöneticiler tarafindan kabul edilen, yaptıkları işe sayg1 duyulan okul psikolojik danışmanlarının öğrencilere ve velilere yönelik psikolojik danışma ve rehberlik faaliyetlerini daha sağlıklı yürütebileceğini söylemek mümkündür. $\mathrm{Bu}$ nedenle, okul psikolojik danışmanlarına mesleki deneyim kazandıracak çalışmalar, okul iklimini iyileştirecek ve okul psikolojik danışmanlarının mesleki gelişimlerine katkı verecek liderlik uygulamaları bu konuda etkili olabilir. Bu araştırma, İzmir ili anakent ilçelerindeki MEB'e bağlı ilk ve orta dereceli resmi ve özel okullarda görev yapan okul psikolojik danışmanlarının psikolojik güçlendirme, öz-yeterlik ve örgütsel özdeşleşme algıları ile sınırlıdır. Araştırmacılar örgütsel özdeşleşme, öz-yeterlik ve psikolojik güçlendirme algılarını başka değişkenlerle ve bunun yanında başka araştırma yöntemleri ile bu bulguları test edebilirler. Ayrıca örgütsel özdeşleşmeye, genel öz-yeterlik yanında mesleki öz-yeterlik alg1sı ve psikolojik güçlendirme yanında yapısal güçlendirme değişkenlerinin de etkisi araştırılabilir.

\section{Kaynaklar}

Argyris, C. (1998). Empowerment: The emperor's new clothes. Harvard Business Review, May-June, 98-105.

Arslantaş, C. C. (2007). Güçlendirici lider davranışının psikolojik güçlendirme üzerindeki etkisini belirlemeye yönelik görgül bir araşturma. Anadolu Üniversitesi Sosyal Bilimler Dergisi, 7(2), 227240.

Ashforth, B. E., Harrison, S. H. \& Corley, K. G. (2008). Identification in organizations: An examination of four fundamental questions. Journal of Management, 34(3), 325-374. DOI: $10.1177 / 0149206308316059$

Ashforth, B. E. \& Mael, F. (1989). Social identity theory and the organization. The Academy of Management Review, 14(1), 20-39.

Aypay, A. (2010). Genel öz yeterlik ölçeği’nin (GÖYÖ) Türkçe’ye uyarlama çalışması. İnönü Üniversitesi Eğitim Fakültesi Dergisi, 11(2), 113-131.

Bandura, A. (1977). Self-efficacy: Toward a unifying theory of behavioral change. Psychological Review, 84(2), 191-215.

Bandura, A. (1986). Social foundations of thought and action: A social cognitive theory. Englewood Cliffs, NJ: Prentice-Hall.

Bartels, J. (2006). Organizational identification and communication: Employees' evaluations of internal communication and its effect on identification at different organizational levels. (Yayımlanmamış Doktora Tezi). University of Twente.

Bogler, R. \& Somech, A. (2004). Influence of teacher empowerment on teachers' organizational commitment, professional commitment and organizational citizenship behavior in schools. Teaching and Teacher Education, 20(3), 277-289.

Bolat, T., (2003). Personeli güçlendirme: Davranışsal ve bilişsel boyutta incelenmesi ve yönetim kavramlarıyla karşılaşturılmas1. Atatürk Üniversitesi İI.I.B.F. Dergisi, 17(3-4), 199-219.

Brown M. E. (1969). Identification and some conditions of organizational involvement. Administrative Science Quarterly, 14(3), 346-355.

Buchanan, B. (1974). Building organizational commitment: The socialization of managers in work organizations. Administrative Science Quarterly, 19(4), 533-546. 
Özgözgü, S., \& Bektaş, M. (2018). Okul psikolojik danışmanlarında örgütsel özdeşleşme: Psikolojik güçlendirme ve özyeterlik inançlarının rolü. Journal of Human Sciences, 15(4), 1993-2011. doi:10.14687/jhs.v15i4.5372

Bulut, E. (2015). Personel güglendirme, örgütsel özdeşleşme ve çalsşan performansı arasindaki ilişki: Katılmm bankalarnda araştırma. (Yayımlanmamıs Yüksek Lisans Tezi). Beykent Üniversitesi, Sosyal Bilimler Enstitüsü, İstanbul.

Caldwell, D. F., Chatman, J. A. \& O'Reilly, C. A. (1990). Building organizational commitment: A multi firm study. Journal of Occupational Psychology, 63, 245-261.

Conger, J. A. \& Kanungo, R. N. (1988). The empowerment process: Integrating theory and practice. Academy of Management Review, 13, 471- 482

Çalışkan, S. C. (2011). Çalışanların psikolojik güçlendirilme algıları üzerinde işyeri arkadaşlıkları ve örgütsel iletişimin etkisi. C.Ü. Sosyal Bilimler Enstitüsü Dergisi, 20(3), 77-92.

Çanak, M. \& Avc1, Ö. Y. (2016). Öğretmenlerin örgütsel özdeşleşme ve örgütsel iletişim düzeylerinin incelenmesi. INESJOURNAL Uluslararası Eğitim Bilimleri Dergisi, The Journal of International Education Science, 3(7), 91-110.

Çırakoğlu, H. (2010). Örgütsel özdeşleşme ve iş doyumu ilişkisi. (Yayımlanmamış Yüksek Lisans Tezi). Dokuz Eylül Üniversitesi Sosyal Bilimler Enstitüsü, İzmir.

Çiftçioğlu, B. A. (2010). Relationship between organizational commitment and organizational identification: A theorical investigation. "IS, GUC" Industrial Relations and Human Resources Journal, 12(1). 71-92. DOI: 10.4026/1303-2860.2010.137.x

Demirtaş, H. A. (2003). Sosyal kimlik kuramı, temel kavram ve varsayımları. İletişim Araștırmalar Dergisi, 1(1), 123-144.

Donat Bacıoğlu, S., Kocabıyık, O. O. \& Malkoç, A. (2017). Rehberlik ve psikolojik danışmanlık öğrencilerinin okullardaki rehberlik servisini değerlendirmeleri. Türk Psikolojik Danısma ve Rebberlik Dergisi, 7(48), 45-62.

Erdoğdu, M. Y. \& Aydındağ, Z. (2013). Öğretmenlerin kurumsal özdeşleşme ve bağllliklarının algılanan yönetici davranışları açısından incelenmesi. Istanbul Sabahattin Zaim Üniversitesi Sosyal Bilimler Enstitüsü, 1 (2), 158-153. http://www.izu.edu.tr/Assets/Content/file/20130613$\underline{10 . p d f}$

Erel Yetim, A. E. (2010). Genel liselerde örgütsel iletişim ile örgütsel özdeşleşme arasindaki ilişki. (Yayımlanmamış Yüksek Lisans Tezi). Gazi Üniversitesi Eğitim Bilimleri Enstitüsü, Ankara.

Eren, E. (2015). Örgütsel davranıs ve yönetim psikolojisi. (15. Baskı) Beta: İstanbul.

Ertürk, A. (2010). Exploring predictors of organizational identification: Moderating role of trust on the associations between empowerment, organizational support, and identification. European Journal of Work and Organizational Psychology, 19(4), 409-441, DOI: $10.1080 / 13594320902834149$

Eryılmaz, A. (2013). Pozitif psikolojinin psikolojik danışmanlık ve rehberlik alanında gelişimsel ve önleyici hizmetler bağlamında kullanilması. The Journal of Happiness \& Well Being, 1(1), 1-21.

Fernandez, S. \& Moldogaziev, T. (2011). A causal model of the empowerment process: Exploring the links between empowerment practices, employee cognitions, and behavioral outcomes. 11th National Public Management Research Conference, Maxwell School, Syracuse University, Syracuse, New York, June 2-4, 2011.

Fiol C. M. (2001). Revisiting and identity-based view of sustainable competitive Advantage. Journal of Management, 27, 691-699.

Givens, R. J. (2008). Transformational leadership: The impact on organizational and personal outcomes. Emerging Leadership Journeys, 1(1), 4-24.

Harris, G. E. \& Cameron, J. E. (2005). Multiple dimensions of organizational identification and commitment as predictors of turnover intentions and psychological well-being. Canadian Journal of Behavioral Science, 37, 159-169.

Johnson, M. D., Morgeson, F. P. \& Hekman, D. R. (2012). Cognitive and affective identification: Exploring the links between different forms of social identification and personality with work attitudes and behavior. Journal of Organizational Behavior, 33, 1142-1167.

Karasar, N. (2005). Bilimsel araştırma yöntemi. Ankara: Nobel Yayın Dağıtım. 
Özgözgü, S., \& Bektaş, M. (2018). Okul psikolojik danışmanlarında örgütsel özdeşleşme: Psikolojik güçlendirme ve özyeterlik inançlarının rolü. Journal of Human Sciences, 15(4), 1993-2011. doi:10.14687/jhs.v15i4.5372

Karataş, Z. \& Şahin Baltacı, H. (2013). Ortaöğretim kurumlarında yürütülen psikolojik danışma ve rehberlik hizmetlerine yönelik okul müdürü, sınıf rehber öğretmeni, öğrenci ve okul rehber öğretmeninin (psikolojik danışman) görüşlerinin incelenmesi. Abi Evran Üniversitesi Kərşehir Eğitim Fakültesi Dergisi (KEFAD), 14(2), 427-460.

Konczak, L. J., Stelly, D. J. \& Trusty, M. L. (2000). Defining and measuring empowering leader behaviors: Development of an upward feedback instrument. Educational and Psychological Measurement, 60(2), 301-313

Korkut, K. \& Babaoğlan, E. (2012). Sınıf öğretmenlerinin öz yeterlik inançları. Uluslararası Yönetim Íktisat ve Isletme Dergisi, 8(16), 269-282.

Korkut Owen, F. \& Owen, D. W. (2008). Okul psikolojik danışmanlarının rol ve işlevleri: Yöneticiler ve psikolojik danışmanlanın görüşleri. Ankara Üniversitesi Eğitim Bilimleri Fakültesi Dergisi, 41(1), 204-218

Köse, C. G. (2009). Örö̈tsel özdeşlessmenin çalışanlarn sürekli iyileştirme çabalarna katkısı: Bir arastırma. (Yayımlanmamış Yüksek Lisans Tezi). İstanbul Üniversitesi Sosyal Bilimler Enstitüsü, İstanbul.

Kurt, T. (2012). Öğretmenlerin öz yeterlik ve kolektif yeterlik alg1lar1. Türk Eğitim Bilimleri Dergisi, 10(2), 195- 227.

Kuzgun, Y. (1991). Rebberlik ve psikolojike danısma (2. baskı). Ankara: ÖSYM Yayınları.

Laschinger, H. K. S., Finegan, J., Shamian, J. \& Wilk, P. (2001). Impact of structural and psychological empowerment on jobs train in nursing work settings expanding Kanter's model. JONA, 31(5), 260-272.

Laschinger, H. K. S., Finegan, J., Shamian, J. \& Wilk, P. (2004). A longitudinal analysis of the impact of work place empowerment on work satisfaction. Journal of Organizational Behavior, 25(4), 527-545.

Lee, S. M. (1971). An empirical analysis of organizational identification. The Academy of Management Journal, 14(2), 213-226.

Leech, N.L., Barrett, K.C. \& Morgan, G.A (2005) SPSS for Intermediate Statistics: Use and Interpretation, 2nd Edition, New Jersey, Lawrence Erlbaum Associates Inc.

Mael, F. \& Ashforth, B. E. (1992). Alumni and their alma mater: A partial test of the reformulated model of organizational identification. Journal of Organizational Behavior, 13(2),103-123.

Menon, S. T. (2001). Emplyoee empowerment: An integrative psychological approach. Applied Psychology: An International Review, 50(1), 153-180.

Meydan, C. H., Polat, M., \& Burmaoğlu, S. (2010). Bireyin güçlendirilmişlik algısının örgütle özdeşleşmesine etkisi: Kamuda bir araştırma. KHO Bilim Dergisi, 20(1), 37-60.

O'Reilly, C. A. \& Chatman, J. A. (1986). Organizational commitment and psychological attachment: The effects of compliance, identification and internalization on prosocial behavior. Journal of Applied Psychology, 71, 492-499.

Özabacı, N., Sakarya, N. \& Doğan, M. (2008). Okul yöneticilerinin okuldaki psikolojik danışma ve rehberlik hizmetlerine ilişkin görüsslerinin değerlendirilmesi. Balkesir Üniversitesi Sosyal Bilimler Enstitüsü Dergisi, 11(19), 8-22.

Özarall, N. (1998). Örgütlerde güglendirme. (İçinde) Endüstri ve Örgüt Psikolojisi-II, Ed: Suna Tevrüz, Ankara: Türk Psikologlar Derneği Yayınları.

Özgözgü, S. (2017). Kurumsal imaj, örgüt kültürü ve örgütsel özdeşleşme ilişkisi. Kastamonu Eğitim Dergisi, 25(2), 581-596.

Özgözgü, S. \& Altunay, E. (2016). Yöneticilerin liderlik davranışlarının öğretmenlere yansıyan sonuçları: Bir meta-analiz çalışması. Manisa Celal Bayar Üniversitesi Sosyal Bilimler Dergisi, 14(4), 259-294.

Pajares, F. (1996). Self-efficacy beliefs in academic settings. Review of Educational Research, 66(4), 543578.

Pamukçu, B. (2011). The investigation of counseling self-efficacy levels of counselor trainees. (Yayımlanmamıs Yüksek Lisans Tezi). Orta Doğu Teknik Üniversitesi, Eğitim Bilimleri Bölümü, Ankara. 
Özgözgü, S., \& Bektaş, M. (2018). Okul psikolojik danışmanlarında örgütsel özdeşleşme: Psikolojik güçlendirme ve özyeterlik inançlarının rolü. Journal of Human Sciences, 15(4), 1993-2011. doi:10.14687/jhs.v15i4.5372

Pamukçu, B. \& Demir, A. (2013). Psikolojik danışma öz-yeterlik ölçeği Türkçe formu’nun geçerlik ve güvenirlik çalışması. Türk Psikolojik Damısma ve Rehberlik Dergisi, 5(40), 212-221.

Polat S. (2009). Yüksekëgrretim örgütlerinde örgütsel imaj yönetimi: Örgütsel imajın öncülleri ve çıtılar. The First International Congress of Educational Research. Çanakkale. http://akademikpersonel.kocaeli.edu.tr/spolat/bildiri/spolat27.02.2011_23.05.28bildiri.pdf (Erişim Tarihi: 01/09/2012)

Polat, M., Meydan, C. H. \& Tokmak, İ. (2010). Personel güçlendirme, örgütsel özdeşleşme ve örgütsel sinizm ilişkisi üzerine bir araştırma. KHO Bilim Dergisi, 20(2), 1-22.

Prati, G. \& Zani, B. (2013). The relationship between psychological empowerment and organizational identification. Journal of Communty Psychology, 41(7), 851-866. DOI: $10.1002 /$ jcop. 21578

Riketta, M. (2005). Organizational identification: A meta-analysis. Journal of Vocational Behavior, 66,358-384.

Spreitzer, G. M. (1995). Psychological empowerment in the workplace: Dimensions, measurement, and validation. The Academy of Management Journal, 38(5), 1442-1465.

Sune, A. (2016). Okul yöneticilerinin örgütsel özdesslesme düreyleri ile örgüt kültürü arasindaki iliski. (Yayımlanmamış Yüksek Lisans Tezi). Kahramanmaraş Sütçü İmam Üniversitesi Sosyal Bilimler Enstitüsü, Kahramanmaraş.

Sürgevil, O., Tolay, E. \& Topoyan, M. (2013). Yapısal güçlendirme ve psikolojik güçlendirme ölçeklerinin geçerlilik ve güvenilirlik analizleri. Journal of Yasar University, 8(31), 5371-5391.

Tarkın, A. \& Uzuntiryaki, E. (2012). Öğretmen adaylarının özyeterlik inançları ve mesleğe yönelik tutumlarının kanonik korelasyon analizi ile incelenmesi. İlkögretim Online, 11(2), 332-341.

Taştan, S. (2012). Bir pozitif psikoloji kavramı olarak örgütle özdeşleşmenin psikolojik güçlendirme alg1sı ve gönüllü performans davranışı arasındaki ilişkide ara değişken rolünün değerlendirilmesi: Gıda sektöründe yapılan bir araştırma. Organizasyon ve Yönetim Bilimleri Dergisi, 4(1), 227-238.

Thomas, K. W. \& Velthouse, B. A. (1990). Cognitive elements of empowerment. Academy of Management Review, 15(4), 666-681.

Tüzün, Kalemci İ. (2006). Örgütsel güven, örgütsel kimlik ve örgütsel özdeşleşme ilişkisi; wygulamah bir çalşsma. (Yayınlanmamış Doktora Tezi), Ankara, Gazi Üniversitesi Sosyal Bilimler Enstitüsü.

Ünal, A. \& Ünal, E. (2010). Öğretmen ve öğrencilerin rehber öğretmeni alg1lamalarına ilişkin bir durum çalışması. Uluslararası Insan Bilimleri Dergisi, 7(2), 919-845.

Van Dick, R. (2001). Identification in organizational contexts: Linking theory and research from social and organizational psychology. International Journal of Management Reviews, 3(4), 265-283.

Van Dick, R., Wagner, U., Stellmacher, J. \& Christ, O. (2004). The utility of a broader conceptualization of organizational identification: Which aspects really matter? Journal of Occupational and Organizational Psychology, 77, 171-191.

Yarmac1, N. (2012). Psikolojik güglendirmenin örgütsel özdeşlesmeye etkisi: Otel işletmelerinde bir arastrma. (Yayımlanmamış Yüksek Lisans Tezi). Afyon Kocatepe Üniversitesi, Sosyal Bilimler Enstitüsü, Afyonkarahisar.

Yeşilyaprak, B. (2006). Eğitimde Rehberlik Hiæ̌metleri (14.baskı). Ankara: Nobel Yayın Dağıtım

Yıldırım, F. \& İlhan, İ. Ö. (2010). Genel özyeterlilik ölçeği Türkçe formunun geçerlik ve güvenilirlik çalışması. Türk Psikizyatri Dergisi, 21(4), 301-308.

Yildiz, K. (2013). Analysis of the relation of teachers' organizational identification and organizational communication. Educational Sciences: Theory \& Practice, 13(1), 264-272.

Y1lmaz, C. (2014). Örgütsel güven ile tükenmişlik arasindaki iliskide algilanan örgütsel özdesslesmenin aracllk etkisi: Uygulamah bir çalısma. (Yayımlanmamış Yüksek Lisans Tezi). Nevşehir Hacı Bektaş Veli Üniversitesi Sosyal Bilimler Enstitüsü, Nevşehir.

Yiyit, F. (2001). Okul psikolojik damısmanlarn yetkinlik beklentilerini ölcmeye yönelik bir ölçek geliștirme çalısması. (Yayınlanmamış Yüksek Lisans Tezi), Adana: Çukurova Üniversitesi Sosyal Bilimler Enstitüsü 
Özgözgü, S., \& Bektaș, M. (2018). Okul psikolojik danışmanlarında örgütsel özdeşleșme: Psikolojik güçlendirme ve özyeterlik inançlarının rolü. Journal of Human Sciences, 15(4), 1993-2011. doi:10.14687/jhs.v15i4.5372

Yüksel, K., Diken, İ. H., Aksoy, V. \& Karaaslan, Ö. (2012). Rehber öğretmen adaylarının özel eğitimde psikolojik danışma ve rehberliğe ilişkin öz-yeterlik algıları. Pamukkkale Üniversitesi Ë̈itim Fakültesi Dergisi, 31, 135-146.

Zhu, W., Sosik, J. J., Riggio, R. E. \& Yang, B. (2012). Relationships between transformational and active transactional leadership and followers' organizational identification: The role of psychological empowerment. Journal of Behavioral \& Applied Management, 13(3), 186-212.

\section{Extended English Summary}

It is known that the identification of the employees with their organization is an important factor to understand the working behavior (Lee, 1971: 213). To Dutton and others (1994: 242), organizational identification is a way of psychological bond that occurs when the members identify with specific features of the organization. To ensure the organizational identification, it is an important indicator how the employees perceive their own efficiency and how much of the power that will evoke those efficiencies they feel. The autonomy in the organization will only be possible if the individual's bond with the organization is strong.

The employee who feels strengthened will be more satisfied with their job and therefore will identify more with their organization (Prati \& Zani, 2013: 852-853). In certain situations such as when the work that is done means something to the individual, when the self-efficacy is high therefore their competence is high, in the meantime when the autonomy is provided and it effects the work output, it can be said that these situations may lead to identification.

\section{Purpose}

In the literature, the interest in the relation between organizational identification, psychological empowerment (Prati \& Zani, 2013: 853) and self-efficacy is limited. In this research, it is aimed to determine the relationship between organizational identification, self-efficacy and psychological empowerment depending on the perceptions of the psychological counselors who work in private and state schools that are subject to Ministry of Education. The problem of the research is created as "Do self-efficacy and psychological empowerment depending on the perceptions of the psychological counselors who work in private and state schools that are subject to Ministry of Education, predict the organizational identification?"

\section{Method}

In this research, the relational screening model is used to examine to what extent the psychological empowerment and general self-efficacy predict the organizational identification. In the research, self-efficacy and psychological strengthening are taken as independent variables and the organizational identification is taken as a dependent variable. The universe of the research is composed of the teachers who work in state and private schools that are subject to Ministry of Education in counties in the city of Izmir. The data of the study were collected in 2016. The data were collected at professional meetings organized by Guidance and Research Centers for psychological counselors and at school visits conducted by researchers. The valid data is collected from 374 people in total.

The "Psychological Empowerment Scale" that is developed by Spreitzer (1995) and adopted to Turkish by Sürgevil, Tolay and Topoyan (2013), the "General Self-Efficacy Scale" that is adapted to Turkish by İlhan (2010) and the "Organizational Identification Scale" that is developed by Van Dick and the others (2004) are used to collect data. In this research, to determine the relationship between self-efficacy, psychological empowerment and organizational identification, Hierarchical Multiple Regression Analysis is used. 
Özgözgü, S., \& Bektaș, M. (2018). Okul psikolojik danışmanlarında örgütsel özdeşleșme: Psikolojik güçlendirme ve özyeterlik inançlarının rolü. Journal of Human Sciences, 15(4), 1993-2011. doi:10.14687/jhs.v15i4.5372

\section{Findings}

In this research it is found that men, people who are above 41 years old, people who have 16 or more years of experience and the people who are graduated from other faculties have better identification with their schools.

When it comes to perception of psychological strength, people who are 41 years old or above, and people who have 21 years of experience or above are found to feel stronger. The perception of general self-efficacy of the participants was higher among the ones who are 41 years old or above. Moreover the participants answered the options of organizational identification, psychological empowerment and general self-efficacy as "I agree".

In this research, there is significant relationship found between the psychological counselors' perception of general self-efficacy, psychological empowerment and organizational identification. Also, an analysis made to see if the independent variables predict the perception of organizational identification. First of all, it is checked if the perception of general self-efficacy predict the perception of organizational identification, and then the findings on if the general selfefficacy and psychological empowerment together predict the organizational identification are compared. According to this outcome, while general self-efficacy alone, predicts organizational identification significantly, as psychological empowerment is added to general self-efficacy, predictive power has significantly increased.

\section{Discussion \& Conclusion}

In this research, comparing to the teachers who are older and have higher seniority, the teachers who are younger and have less seniority have lower perception of self-efficacy, psychological empowerment and organizational identification. Therefore more attention should be paid especially to the applications done on the psychological counselors who are younger and less senior. Solansky (2014) stated that the experience has a positive relationship with the psychological empowerment and as the experience increases, the perception of psychological empowerment increases too.

In the research, there is significant relationship found between the perceptions of general self-efficacy, psychological empowerment and organizational identification. In literature, the findings in various studies also support this statement. Besides that, as a result of series of analysis, general self-efficacy and psychological empowerment predict psychological counselors' perception of organizational identification. In order to ensure the school psychological counselors' identification with their schools, it is needed to increase their general self-efficacy and strengthen them psychologically. It is only possible to provide the effectiveness of the employees and therefore the success of the organization, when the employees who work in the organization are strengthened.

\section{Suggestions}

The productivity of the employees will increase when they identify with the organization's qualities. In this context, it is seen that school counselors' organizational identification is affected by their belief of general self-efficacy and their perception of psychological empowerment. The studies that will make school psychological counselors gain some professional experience; leadership practices that will enhance the school's climate and support the school psychological counselors' professional development can be very effective on this subject. 